Antunović, Z., Senčić, Đ., Klir, Ž., Zmaić, K., Samac, D., Novoselec, J. (2020): Organic livestock farming in Republic of Croatia- state and perspective development. Agriculture and Forestry, 66 (3): 7-13.

DOI: 10.17707/AgricultForest.66.3.01

\author{
Zvonko ANTUNOVIĆ, Đuro SENČIĆ, Željka KLIR, \\ Krunoslav ZMAIĆ, Danijela SAMAC and Josip NOVOSELEC ${ }^{1}$
}

\title{
ORGANIC LIVESTOCK FARMING IN REPUBLIC OF CROATIA- STATE AND PERSPECTIVE DEVELOPMENT
}

\section{SUMMARY}

Recently, in the Republic of Croatia an increase in organic farming was observed. The aim of this paper is to present the state and perspectives of organic livestock farming development in Croatia during recent five years. There has been an increase in the number of organic farmers by $114 \%$ and the number of organic processors by $52.28 \%$. The used agricultural land decreased by $1.54 \%$, while the land under organic production in total used agricultural land increased, which is $6.94 \%$. Areas sown with crops important for organic livestock feeding increased the most for rapeseed and green forage from arable land and gardens and a decrease was observed in oats. The largest increase regarding livestock was in the number of Equidae and sheep and goats, while the only decrease was observed in poultry. The largest increase was also found for sheep meat, beef and pork, while in dairy production the largest increase was in goat milk, as well as production of cheese. Expansion of organic production is observed in the recent five years in Croatia. This contributes to the growing interest in organic production, as indicated by increases in the analyzed indicators in the organic livestock sector.

Keywords: organic livestock farming; the Republic of Croatia; state and perspectives of development.

\section{INTRODUCTION}

Organic agriculture in the world has been the fastest growing branch of agricultural production in recent years. The Republic of Croatia has recorded significant increase in organic agriculture with the same trend in organic livestock farming. The reasons for the abovementioned can be seen through Croatia's outstanding natural resources as well as their conservation and the development of organic agriculture, which all contribute to the development of a country based on natural and ethical principles, without which no development is complete

\footnotetext{
${ }^{1}$ Zvonko Antunović, (corresponding author: zantunovic@fazos.hr), Đuro Senčić, Željka Klir, Krunoslav Zmaić, Danijela Samac, Josip Novoselec, Faculty of Agrobiotechnical Sciences Osijek, J. J. Strossmayer University of Osijek, V. Preloga 1, 31000 Osijek, CROATIA Paper presented at the GEA (Geo Eco-Eco Agro) International Conference 2020, Podgorica. Notes: The authors declare that they have no conflicts of interest. Authorship Form signed online. 
(Senčić et al., 2011). Favorable climatic conditions, the possibility of producing cheap and good quality food, large quantities of floorcloth, smaller financial investments and the possession of certified organic land areas are very good prerequisites for the spread of organic livestock farming in the Republic of Croatia (Antunović, 2011; Gugić et al., 2017). The aim of organic livestock farming is to obtain high-quality food for human consumption, but also to ensure animal welfare and environmental protection (Senčić et al., 2011). Organic livestock production encourages the use of natural sources in a particular breeding area, grazing, open barns and canopies, which ensures better adaptation of animals to environmental conditions (Antunović, 2011). In the common market of the European Union, the advantages of the Republic of Croatia are, among other things, reflected in the possibility of developing organic agriculture, including organic livestock farming, and through the integration with tourism, as well as the protection of native plant and animal genetic resources and the conservation of biodiversity. According to the data of the Croatian Chamber of Economy, cited in the Ministry of Agriculture's Annual Report on the State of Agriculture in year 2018, it was pointed out that the annual value of the Croatian market of organic products is around 100 million EUR, which is certainly not negligible, while the share of consumption of organic products in total consumption is $2.2 \%$. Thus, the aim of this paper is to present the state and perspectives of the development of organic livestock farming in the Republic of Croatia, by analyzing the period of the recent five years.

\section{STATE AND PERSPECTIVES OF DEVELOPMENT OF ORGANIC LIVESTOCK FARMING IN THE REPUBLIC OF CROATIA}

In the Republic of Croatia in the recent five years there has been an increase in the number of organic farmers by $114 \%$ and in the number of organic processors by $52.28 \%$.

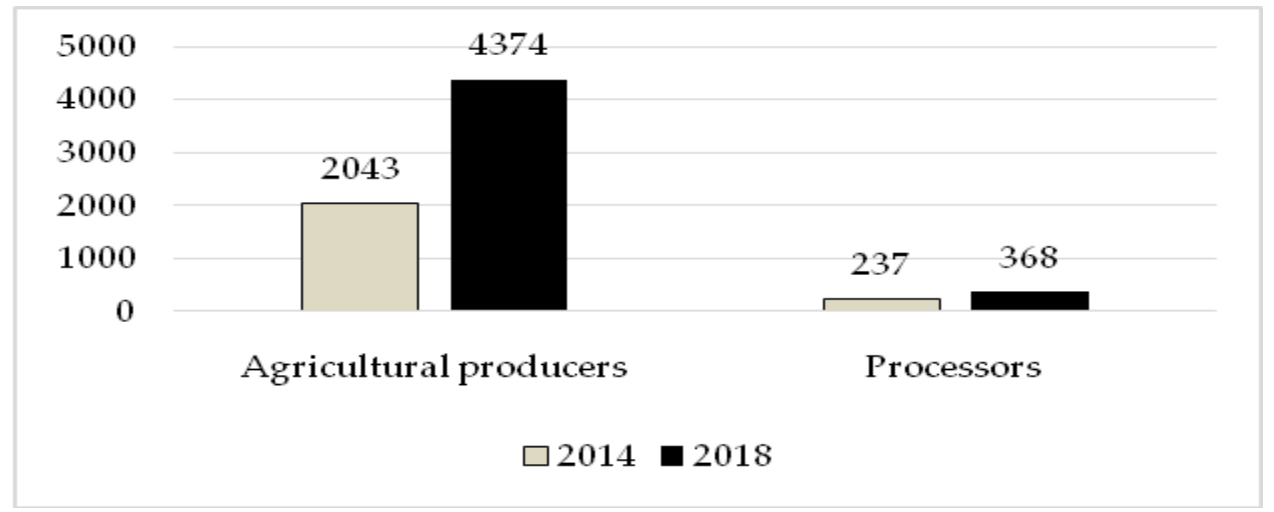

Figure 1. Number of organic agricultural entities in the Republic of Croatia in the last five years (Croatian Bureau of Statistics, 2019). 
During the recent five years, the first five entities in the processing and preserving of meat and its products have been registered in the Republic of Croatia. Likewise, the number of registered producers of plant and animal oils and fats were also increased significantly by $121.62 \%$, as well as the number of dairy producers by $37.50 \%$.

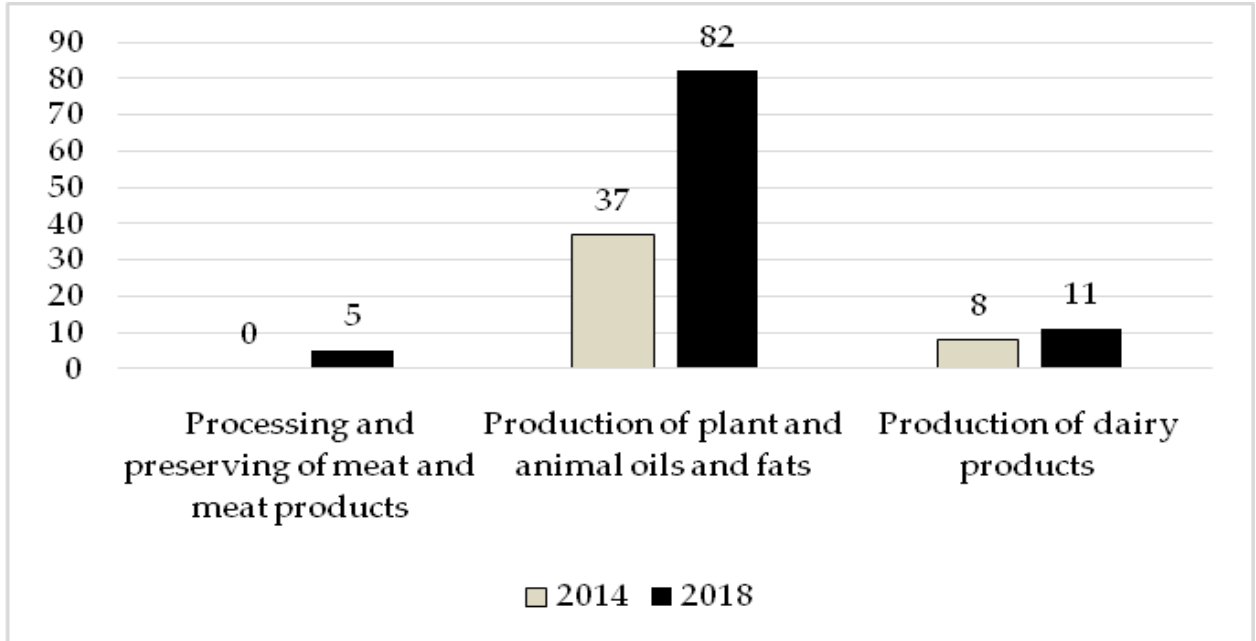

Figure 2. Number of processors of organic livestock products (Croatian Bureau of Statistics, 2019).

Table 1. The area of utilized agricultural land and area under organic production in the last five years in the Republic of Croatia (Croatian Bureau of Statistics, 2019).

\begin{tabular}{|l|c|c|c|}
\hline Year & $\begin{array}{c}\text { Agricultural } \\
\text { land used, } \\
\text { (ha) }\end{array}$ & $\begin{array}{c}\text { Areas under } \\
\text { organic } \\
\text { production, } \\
\text { (ha) }\end{array}$ & $\begin{array}{c}\text { Share of areas under } \\
\text { organic production in } \\
\text { total utilized } \\
\text { agricultural area, \% }\end{array}$ \\
\hline 2014 & 1508885 & 50054 & 3.32 \\
\hline 2015 & 1537629 & 75883 & 4.94 \\
\hline 2016 & 1546019 & 93814 & 6.07 \\
\hline 2017 & 1496663 & 966185 & 6.46 \\
\hline 2018 & 1485645 & 103166 & 6.94 \\
\hline Difference (2014-2018), \% & -1.54 & +51.48 & \\
\hline
\end{tabular}

The area of utilized agricultural land in the Republic of Croatia has decreased by $1.54 \%$ in the recent five years, while the area under organic production has increased significantly from 50.054 ha to 103.166 ha, which is an increase of $51.48 \%$ (Table 1). In the recent five years there has also been an increase in the share of areas under organic production in total utilized agricultural area from $3.32 \%$ in 2014 to $6.94 \%$ in 2018. Although significant 
increase of areas under organic production in total utilized agricultural area in the Republic of Croatia has been identified in the recent five years, although anticipated increase from the Action Plan of the Ministry of Agriculture has not yet been fully realized, where an increase of $8 \%$ is expected by 2016 . The Ministry of Agriculture of the Republic of Croatia in the year 2011 adopted an Action plan of development of organic agriculture with the objective to accelerate the development of organic livestock farming, and to ensure supply primarily the Croatian market, and also ensure the placement of organic products abroad. According to Antunović et al. (2016) limiting factors in the development of organic agriculture are depopulation of rural areas, unfavorable educational structure, insufficient education of farmers and consumers of organic products, problems with unresolved land ownership along with numerous cropped and scattered land areas as well as mined areas.

Table 2. Total area of organic crops from arable land most commonly used in livestock feeding and their organic production in the recent five years in the Republic of Croatia (Croatian Bureau of Statistics, 2019).

\begin{tabular}{|l|c|c|c|c|c|c|}
\hline \multirow{2}{*}{ Crop } & \multicolumn{5}{|c|}{ Surface, ha } & $\begin{array}{c}\text { Trend, } \\
\text { \% }\end{array}$ \\
\cline { 2 - 6 } & $\mathbf{2 0 1 4}$ & $\mathbf{2 0 1 5}$ & $\mathbf{2 0 1 6}$ & $\mathbf{2 0 1 7}$ & $\mathbf{2 0 1 8}$ & \\
\hline $\begin{array}{l}\text { Arable land and } \\
\text { gardens }\end{array}$ & 27459 & 34281 & 44147 & 44083 & 50281 & +83.11 \\
\hline Wheat and spelt & 3654 & 4680 & 6011 & 4785 & 6376 & +74.49 \\
\hline Barley & 1081 & 783 & 1487 & 1351 & 1358 & +7.10 \\
\hline Oat & 1235 & 905 & 1557 & 0418 & 1108 & -10.28 \\
\hline Corn, dry grain & 1768 & 2174 & 2185 & 2506 & 3102 & +75.80 \\
\hline Rapeseed & 1293 & 1034 & 2421 & 3699 & 4079 & +215.47 \\
\hline Sunflower & 1520 & 1335 & 1438 & 2175 & 2112 & +38.95 \\
\hline Soybean & 1339 & 2607 & 2563 & 2826 & 2286 & +70.72 \\
\hline $\begin{array}{l}\text { Green forage from } \\
\text { arable land and } \\
\text { gardens }\end{array}$ & 10023 & 12221 & 16860 & 16248 & 20002 & +99.56 \\
\hline
\end{tabular}

Analysis of Tables 2 and 3 viewed crops (agricultural crops) used in organic farming for animal feeding which plays a significant part in composition of their diets. It can be seen that the largest increase in the area over the past five years was sown with rapeseed (by 215.47\%) and the area under green forage from arable land and gardens increased by $99.56 \%$, while the area under oats decreased by $10.28 \%$. This has been influenced by the various incentives for organic production, and green payments. It is also evident that production has increased in all prominent crops (agricultural crops). According to the analysis of production over the past five years, the largest increase was recorded for maize (dry grain) by $395.36 \%$, soybeans by $395.05 \%$ and wheat and spelt by $380.28 \%$. 
Table 3. Total organic production of crops (agricultural crops) in the last five years in the Republic of Croatia (Croatian Bureau of Statistics, 2019).

\begin{tabular}{|c|c|c|c|c|c|c|}
\hline \multirow{2}{*}{ Crop } & \multicolumn{5}{|c|}{ Production, $\mathbf{t}$} & \multirow{2}{*}{$\begin{array}{c}\text { Trend, } \\
\%\end{array}$} \\
\hline & 2014 & 2015 & 2016 & 2017 & 2018 & \\
\hline $\begin{array}{l}\text { Arable land and } \\
\text { gardens }\end{array}$ & 71889 & 102694 & 149698 & 149535 & 144563 & +101 \\
\hline Wheat and spelt & 4493 & 11664 & 19459 & 17416 & 21579 & +380.28 \\
\hline Barley & 3375 & 2480 & 3409 & 4497 & 4114 & +21.90 \\
\hline Oat & 1474 & 1777 & 3437 & 3184 & 2206 & +49.66 \\
\hline Corn, dry grain & 4285 & 11921 & 18273 & 17295 & 21226 & +395.36 \\
\hline Rapeseed & 2751 & 2309 & 4953 & 8877 & 8898 & +223.45 \\
\hline Sunflower & 1900 & 2278 & 3044 & 6279 & 6047 & +218.26 \\
\hline Soybean & 1130 & 5839 & 6145 & 7493 & 5594 & +395.05 \\
\hline $\begin{array}{l}\text { Green forage from } \\
\text { arable land and } \\
\text { gardens }\end{array}$ & 44978 & 52467 & 80929 & 74080 & 88923 & +97.71 \\
\hline
\end{tabular}

Table 4 shows the number of livestock heads in organic farming by species in the recent five years in the Republic of Croatia. The largest increase was recorded in the number of Equidae (by $720.60 \%$ ) and in the number of sheep and goats by $187.30 \%$ and $170.55 \%$, respectively. The only decrease was in the number of poultry (by $26.38 \%$ ). The reason for that is the inclusion of grant for organic production, as well as the inclusion of grants related to production.

Table 4. Number of heads of livestock in organic farming by species in the recent five years in the Republic of Croatia (Croatian Bureau of Statistics, 2019).

\begin{tabular}{|l|c|c|c|c|c|c|}
\hline \multirow{2}{*}{ Species } & \multicolumn{5}{|c|}{ Year } & \multirow{2}{*}{ Trend, \% } \\
\cline { 2 - 6 } & $\mathbf{2 0 1 4}$ & $\mathbf{2 0 1 5}$ & $\mathbf{2 0 1 6}$ & $\mathbf{2 0 1 7}$ & $\mathbf{2 0 1 8}$ & \\
\hline Cattle & 7308 & 7002 & 14442 & 17226 & 19613 & +168.38 \\
\hline Pigs & 961 & 1114 & 1083 & 1468 & 1887 & +96.36 \\
\hline Sheep & 21690 & 23774 & 50135 & 54583 & 62315 & +187.30 \\
\hline Goats & 1552 & 2163 & 3080 & 3381 & 4199 & +170.55 \\
\hline Poultry & 2540 & 2093 & 3388 & 2174 & 1870 & -26.38 \\
\hline Equidae & 291 & 265 & 1753 & 1929 & 2388 & +720.60 \\
\hline $\begin{array}{l}\text { Bee } \\
\text { colonies }\end{array}$ & 3649 & 3418 & 2065 & 1721 & 2022 & -44.59 \\
\hline
\end{tabular}

The analysis of the data presented in Table 5 shows a significant trend of increasing the majority of organic animal products in the past five years in the Republic of Croatia, with the exception of the organic honey, which production decreased by $48.33 \%$. The largest increase was found for sheep meat, beef and pork. Analyzing the production of organic milk, the largest increase was in the 
production of goat milk, and significant increase was observed in the production of cheese.

The increase in the production of organic animal products is also influenced by the introduction of various grants, as well as the increased interest in organic products purchase.

Table 5. Organic animal products in the recent five years in the Republic of Croatia (Croatian Bureau of Statistics, 2019).

\begin{tabular}{|l|c|c|c|c|c|c|}
\hline \multirow{2}{*}{ Product, t } & \multicolumn{5}{|c|}{ Year } & \multirow{2}{*}{ Trend, \% } \\
\cline { 2 - 7 } & $\mathbf{2 0 1 4}$ & $\mathbf{2 0 1 5}$ & $\mathbf{2 0 1 6}$ & $\mathbf{2 0 1 7}$ & $\mathbf{2 0 1 8}$ & \\
\hline Meat*, total & 109 & 1200 & 1689 & 1627 & 2185 & +1904.6 \\
\hline Beef & 75 & 811 & 1110 & 1133 & 1456 & +1841.0 \\
\hline Pork & 10 & 60 & 91 & 57 & 141 & +1310.0 \\
\hline Sheep meat & 22 & 316 & 474 & 424 & 571 & +2495.5 \\
\hline Goat meat & 2 & 13 & 14 & 13 & 17 & +750.0 \\
\hline Milk, total & 1782 & 6000 & 5163 & 5783 & 3094 & +73.63 \\
\hline Cows' milk & 1700 & 5947 & 5023 & 5671 & 2846 & +67.41 \\
\hline Sheep milk & 51 & - & 38 & 28 & 73 & +43.14 \\
\hline Goat milk & 31 & 40 & 102 & 84 & 175 & +464.52 \\
\hline Cheese & 4 & 13 & 8 & 7 & 43 & +975.0 \\
\hline Table eggs, peaces & 65000 & 117775 & 246890 & 206000 & 183000 & +181.54 \\
\hline Honey & 60 & 48 & 47 & 29 & 31 & -48.33 \\
\hline
\end{tabular}

*All kinds of meat included meat from younger categories of named animal species

For further significant development of organic livestock farming, it is crucial to address, apart from land restrictions, a difficulty in procuring good quality breeding material originating from organic farming and good quality organic feedstuffs for balancing animal rations, especially in highly demanding production stages (gravidity, lactation). Insufficient promotion, undeveloped market, misuse of the "ECO" label for the purpose of product promotion, and insufficient education of farmers and consumers of organic animal products are important facts that should be eliminated as soon as possible for the purpose of development of organic livestock farming. The perspective of organic livestock farming development in Croatia is very good. The richness of natural resources, regulated legislation on organic agriculture and incentive for the development of environmentally friendly tourism related to the revitalization of rural areas, along with initiatives for introduction of "smart villages", as well as various incentive of the Ministry of Agriculture for organic production are good support for the further development of organic livestock farming in Croatia. The large number of protected areas and the introduction of GMO-free zones by almost all Croatian counties are also advantages for the development of organic livestock farming in Croatia. In addition, there is a growing demand for organic animal products not only in Croatia but also more widely, which also contributes to the increased 
interest in this production and contributes to its higher quality perspective for development.

\section{CONCLUSIONS}

An analysis of organic livestock farming in the recent five years in the Republic of Croatia shows the expansion of this production, some difficulties, and significant advantages that contribute to its overall positive image. This has also contributed to the growing interest of this production, which is indicated by significant increase of analyzed indicators, not only by farmers but also by consumers of organic animal products, as well as by those users whose perception of environmental protection and biodiversity are especially emphasized.

\section{CONFLICTS OF INTEREST}

The authors declare no conflict of interest.

\section{REFERENCES}

Antunović, Z. (2011). Organic farming of sheep and goats. In Đ. Senčić, eds. Organic zootechnique, Faculty of Agriculture in Osijek, pp. 92-122.

Antunović, Z., Novoselec, J., Klir,. Ž. (2016): Organic sheep and goat farming in the Republic of Croatia - state and development perspectives. Proceeding of the 51st croatian and 11th international symposium of agriculture, 15-18 February, Opatija, Croatia, pp. 306-310.

European Union (2007): Council Regulation (EC) No. 834/2007. on organic production and labeling of organic products with regard to organic production, labeling and control. Official Journal of the European Union [Online] (Available on-line with updates http://32007R0834) (verified $2^{\text {nd }} 30$ August 2017).

Gugić, J., Grgić, I., Dorbić, B., Šuste, M., Džepina, M., Zrakić, M. (2017): Status overview and development prospect of organic agriculture in Croatia. Glasnik zaštite bilja, 60: 1, 20-30.

Ministry of Agriculture (2019): Annual report. Sheep, goats, and small animals. Križevci, p. 88 .

Senčić, Đ., Antunović, Z., Mijić, P., Baban, M., Puškadija, Z. (2011): Organic zootechnique. Faculty of Agriculture in Osijek, p. 239.

Annual Report on the state of agriculture in year 2018. Ministry of Agriculture, Zagreb (available

https://poljoprivreda.gov.hr/UserDocsImages/dokumenti/poljoprivredna_politika/zel eno_izvjesce/2019_11_13_Zeleno\%20izvjesce2018.pdf

Action plan for the development of organic agriculture in the Republic of Croatia for the period 2011-2016 (2011): Ministry of Agriculture. Zagreb p. 37.

Ministry of Agriculture of the Republic of Croatia ( available at www.mp.hr)

Bureau of Statistics (available at www.dzs.hr) 